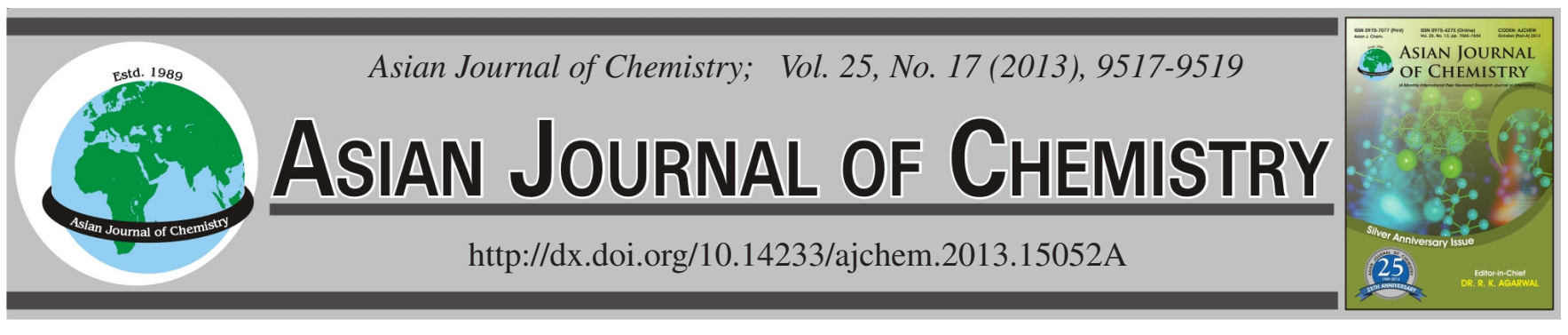

\title{
Isolation of Chalcones from the Root of Codonopsis cordifolioidea and Their Antitobacco Mosaic Virus Activities
}

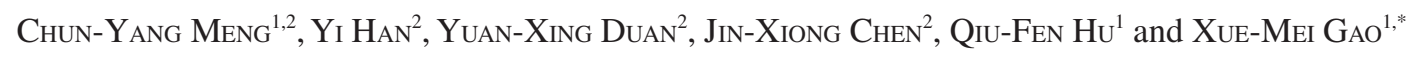

${ }^{1}$ Key Laboratory of Chemistry in Ethnic Medicinal Resources, State Ethnic Affairs Commission \& Ministry of Education, Yunnan University of Nationalities, Kunming 650031, P.R. China

${ }^{2}$ Key Laboratory of Tobacco Chemistry of Yunnan Province, Yunnan Academy of Tobacco Science, Kunming 650106, P.R. China

*Corresponding authors: E-mail: gao_xuemei@hotmail.com

(Received: 31 December 2012;

Accepted: 1 October 2013)

AJC-14218

A new chalcone, 4'-acetoxy-5-hydroxy-6-methoxy-chalcone (1) and four known chalcones (2-5) were isolated from the roots of Codonopsis
cordifolioidea. Their structures were elucidated by spectroscopic methods, including extensive 1D and 2D NMR techniques. Compounds
$\mathbf{1 - 5}$ were tested for their antitobacco mosaic virus activities. Compounds $\mathbf{1}(20 \mu \mathrm{M})$ showed moderate anti tobacco mosaic virus activity
with inhibition rates of $18.2 \%$. Compounds $\mathbf{2 - 5}$ showed low anti tobacco mosaic virus activities with inhibitory rates below $10 \%$.
Key Words: Chalcone, Codonopsis cordifolioidea, Antitobacco mosaic virus activities.

\section{INTRODUCTION}

Some of Codonopsis species such as C. pilosula and $C$. tangshen are commonly used as herbal remedies due to their tonic effects ${ }^{1}$. In addition, the roots of some Codonopsis species, such as Codonopsis cordifolioidea, are locally known as Choushen and have been used as a food in Yunnan, Tibet and Sichuan Provinces since ancient times ${ }^{2,3}$. Meanwhile, as an important economic plant, this species has been widely cultivated in several areas of Yunnan province ${ }^{4,5}$. The previous phytochemical studies on $C$. cordifolioidea have revealed that phenylpropanoids, lignans, as well as flavonoids are major components isolated from this plant ${ }^{5-9}$.

Motivated by searching for bioactive metabolites from this plant, the phytochemical investigation on C. cordifolioidea was carried out. As a result, a new chalcone (1) and four known chalcones (2-5) were isolated from this plant. In addition, the antitobacco mosaic virus (anti TMV) activities of compounds 1-5 were evaluated. This article deals with the isolation, structural elucidation and biological activities of these compounds.

\section{EXPERIMENTAL}

General methods: UV spectra were obtained on a Shimadzu UV-2401A spectrophotometer. IR spectra were obtained in $\mathrm{KBr}$ disc on a Bio-Rad Wininfmred spectrophotometer. ESIMS were measured on a VG Auto Spec-3000 MS spectrometer. ${ }^{1} \mathrm{H},{ }^{13} \mathrm{C}$ and $2 \mathrm{D}$ NMR spectra were recorded on Bruker DRX500 instrument with TMS as internal standard. Column chromatography was performed on silica gel (200-300 mesh), or on silica gel H (10-40 m, Qingdao Marine Chemical Inc., China). Preparative HPLC was used an Agilent 1100 HPLC equipped with ZORBAX-C $\mathrm{C}_{18}(21.2 \mathrm{~mm} \times 250 \mathrm{~mm}, 7.0 \mu \mathrm{m})$ column and DAD detector.

The roots of C. cordifolioidea were collected in Cuxiong Prefecture, Yunnan Province, People's Republic of China, in September 2010. The identification of the plant material was verified by Prof. Chen Y.J. (Yunnan University of Nationalities). A voucher specimen (YNNI 09-9-22) has been deposited in our laboratory.

Extraction and isolation: The air-dried and powdered roots of $C$. cordifolioidea $(2.8 \mathrm{~kg})$ were extracted four times with $70 \%$ methanol $(4 \mathrm{~L} \times 3 \mathrm{~L})$ at room temperature and filtered. The crude extract (147 g) was applied to silica gel (200-300 mesh) column chromatography, eluting with a chloroform-acetone gradient system (20:1, 9:1, 8:2, 7:3, 6:4, 5:5), to give six fractions A-F. The further separation of fraction $\mathrm{C}$ $(8: 2,16.2 \mathrm{~g})$ by silica gel column chromatography, eluted with chloroform-methanol $(9: 1,8: 2,7: 3,6: 4,1: 1)$, yielded mixtures C1-C5. Fraction C1 $(9: 1,3.4 \mathrm{~g})$ was subjected to preparative HPLC (46\% methanol, flow rate $12 \mathrm{~mL} / \mathrm{min}$ ) to give 1 (14.2 $\mathrm{mg}), 4$ (18.8 mg) and 5 (28.6 mg). Fraction C2 (8:2, $2.8 \mathrm{~g})$ was subjected to preparative HPLC (40\% methanol, flow rate $12 \mathrm{~mL} / \mathrm{min}$ ) to give 2 (18.8 $\mathrm{mg}$ ) and $3(22.1 \mathrm{mg})$.

Anti tobacco mosaic virus assays: The anti tobacco mosaic virus activities were tested using the half-leaf method ${ }^{20}$. Ningnanmycin (2\% water solution), a commercial product for plant disease in China, was used as a positive control. 
4'-Acetoxy-5-hydroxy-6-methoxy-chalcone (1): Yellow gum; UV (MeOH), $\lambda_{\max }(\log \varepsilon) 375$ (3.98), 312 (3.74), 252 (3.69), 230 (4.22) nm; IR (KBr, $\left.v_{\max }, \mathrm{cm}^{-1}\right): 3359,2964,2905$, 1728, 1672, 1614, 1546, 1485, 1267, 1146, 1052, 872, 758; ${ }^{1} \mathrm{H}$ and ${ }^{13} \mathrm{C}$ NMR data $\left(\mathrm{CDC}_{3}, 500\right.$ and $125 \mathrm{MHz}$, respectively) see Table-1; ESIMS (positive ion mode) $\mathrm{m} / \mathrm{z} 349[\mathrm{M}+$ $\mathrm{Na}]^{+}$; HRESIMS (positive ion mode) $\mathrm{m} / z 349.0682\left[\mathrm{M}+\mathrm{Na}^{+}\right.$ (calcd. (\%) 349.0688 for $\mathrm{C}_{18} \mathrm{H}_{14} \mathrm{O}_{6} \mathrm{Na}$ ).

\begin{tabular}{|c|c|c|c|c|c|}
\hline \multicolumn{6}{|c|}{$\begin{array}{c}\text { TABLE- } 1 \\
{ }^{1} \mathrm{H}_{\text {AND }}{ }^{13} \mathrm{C} \text { NMR DATA OF CC } \\
\left(\text { DATA OBTAINED IN } \mathrm{CDCl}_{3}, 500\right.\end{array}$} \\
\hline No. & $\delta_{\mathrm{C}}(\mathrm{m})$ & $\begin{array}{c}\delta_{\mathrm{H}} \\
(\mathrm{m}, J, \mathrm{~Hz})\end{array}$ & No. & $\delta_{\mathrm{C}}(\mathrm{m})$ & $\begin{array}{c}\delta_{\mathrm{H}} \\
(\mathrm{m}, J, \mathrm{~Hz})\end{array}$ \\
\hline 2 & $151.2 \mathrm{~s}$ & - & $1^{\prime}$ & $123.9 \mathrm{~s}$ & - \\
\hline 3 & $115.5 \mathrm{~d}$ & $7.56, \mathrm{~s}$ & $2^{\prime}, 6^{\prime}$ & $129.8 \mathrm{~d}$ & $7.85, \mathrm{~d}, J=8.6$ \\
\hline 4 & $106.2 \mathrm{~d}$ & $7.13, \mathrm{~s}$ & $3^{\prime}, 5^{\prime}$ & $120.5 \mathrm{~d}$ & $7.20, \mathrm{~d}, J=8.6$ \\
\hline 5 & $145.8 \mathrm{~s}$ & - & $4^{\prime}$ & $153.9 \mathrm{~s}$ & - \\
\hline 6 & $148.2 \mathrm{~s}$ & - & OMe-6 & $55.9 \mathrm{q}$ & $3.87, \mathrm{~s}$ \\
\hline 7 & $101.0 \mathrm{~d}$ & $6.88, \mathrm{~s}$ & $\mathrm{Ar}-\mathrm{OH}-4^{\prime}$ & & 9.18, brs \\
\hline 8 & $156.6 \mathrm{~s}$ & - & 1" & $169.2 \mathrm{~s}$ & - \\
\hline 9 & $126.2 \mathrm{~s}$ & - & $2^{\prime \prime}$ & $21.1 \mathrm{q}$ & $2.05, \mathrm{~s}$ \\
\hline 10 & $186.6 \mathrm{~s}$ & - & - & - & - \\
\hline
\end{tabular}

A $70 \%$ aq. methanol extract prepared from the roots of C. cordifolioidea was subjected repeatedly to column chromatography on Si gel, Sephadex LH-20, RP-18 and preparative HPLC to afford a new chalcone, 4'-acetoxy-5-hydroxy-6methoxy-chalcone (1) and four known chalcones (2-6), the structures of the compounds 1-5 were as shown in Fig. 1 and the ${ }^{1} \mathrm{H}$ and ${ }^{13} \mathrm{C}$ NMR data of compound 1 were listed in Table-1. The known compounds, compared with literature, were identified as 4,2',4'-trihydroxy-chalcone $(2)^{10}, 4,2^{\prime}$-dihydroxy-4'methoxy-chalcone $(3)^{10}$, 4-hydroxylonchocarpin $(\mathbf{4})^{11}$ and crotmadine $(\mathbf{5})^{12}$.<smiles>COc1cc2oc(C(=O)c3ccc(OC(=O)F)cc3)cc2cc1O</smiles><smiles>[R]Oc1ccc(C(=O)/C=C/c2ccc(O)cc2)c(O)c1</smiles>
$2 \mathrm{R}=\mathrm{H} ; 3 \mathrm{R}=\mathrm{Me}$<smiles>CC(C)(C)C1=CC=Cc2c(ccc(C(=O)/C=C/c3ccc(O)cc3)c2O)O1</smiles><smiles>CC1(C)CCc2c(O)ccc(C(=O)/C=C/c3ccc(O)cc3)c2O1</smiles>

Fig. 1. Structure of chalcones from the flowers of C. cordifolioidea

The HRESIMS of compound 1 showed a quasi-molecular ion peak at $m / z 349.0688[\mathrm{M}+\mathrm{Na}]^{+}$, corresponding to a molecular formula of $\mathrm{C}_{18} \mathrm{H}_{14} \mathrm{O}_{6}$. The ${ }^{1} \mathrm{H}$ and ${ }^{13} \mathrm{C}$ NMR spectrum of 1 (Table-1) displayed 18 carbon and 14 proton signals, respectively, corresponding to two aromatic rings (C-4-C-9 and C-1'-C-6'), a carbonyl carbon (C-10), a pair of double bond (C-2 and C-3), a methoxy group $\left(\delta_{\mathrm{C}} 55.9\right.$ and $\left.\delta_{\mathrm{H}} 3.87\right)$, an acetoxy group $\left(\delta_{\mathrm{C}} 169.2,21.2 ; \delta_{\mathrm{H}} 2.05\right)$ and a phenolic hydroxy group $\left(\delta_{H} 9.18\right)$. Strong absorption bands accounting for hydroxy $\left(3359 \mathrm{~cm}^{-1}\right)$, carbonyl $(1728,1672)$ and aromatic groups $\left(1614,1546,1485,1267 \mathrm{~cm}^{-1}\right)$ could be observed in its IR spectrum. The UV absorptions at 375, 312, 252 and 230 $\mathrm{nm}$ also suggested the presence of a conjugated aromatic ring system. The NMR data of C-2 $\left(\delta_{\mathrm{C}} 151.2\right), \mathrm{C}-3\left(\delta_{\mathrm{C}} 115.5\right)$, $\mathrm{C}-10\left(\delta_{\mathrm{C}} 186.6\right)$ and $\mathrm{H}-3\left(\delta_{\mathrm{H}} 7.56, \mathrm{~s}\right)$, together with the HMBC correlations (Fig. 2) of H-3 with C-2/C-4/C-8/C-9/C-10, suggested that 1 should be a chalcone derivative fused with a furan ring at C-2 and C- $8{ }^{13}$. The signals for four coupled aromatic protons at $\delta_{\mathrm{H}} 7.03(\mathrm{~d}, J=8.6 \mathrm{~Hz}, 2 \mathrm{H})$ and $7.74(\mathrm{~d}, J$ $=8.6,2 \mathrm{H})$, suggested a $4^{\prime}$-monosubstituted for $\mathrm{C}$ ring $^{14}$ and the proton signals for two singlets at $\delta_{\mathrm{H}} 7.29(\mathrm{~s}, 1 \mathrm{H})$ and $\delta_{\mathrm{H}}$ $6.69(\mathrm{~s}, 1 \mathrm{H})$ also revealed that the substituents for B-ring should be located at C-5 and C- $6^{15}$. The HMBC correlations (Fig. 2) between the methoxy proton signals $\left(\delta_{\mathrm{H}} 3.87\right)$ and C-6 $\left(\delta_{\mathrm{C}}\right.$ 148.2) suggested the positions of the methoxy groups at C-6. On the other hand, the phenolic hydroxy group at C-5 was supported by the HMBC correlations observed between the hydroxy proton $\left(\delta_{\mathrm{H}} 9.18\right)$ and $\mathrm{C}-4\left(\delta_{\mathrm{C}} 106.2\right), \mathrm{C}-5\left(\delta_{\mathrm{C}} 145.8\right)$ and C- $6\left(\delta_{\mathrm{C}} 148.2\right)$. Since the positions of methoxy and hydroxy groups were determined, the acetoxy group should belocated C-4' to support the 4'-monosubstitution for $\mathrm{C}$ ring. On the basis of the above observations, the structure of $\mathbf{1}$ was elucidated as 4'-acetoxy-5-hydroxy-6-methoxy-chalcone.

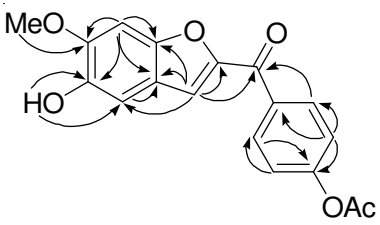

Fig. 2. Selected HMBC ( $)$ correlations of compound $\mathbf{1}$

Many polyphenols are known to exhibit anti tobacco mosaic virus activities ${ }^{16-19}$. Compounds $\mathbf{1 - 5}$ were therefore tested for anti tobacco mosaic virus activities using the halfleaf method ${ }^{20}$. Ningnanmycin, a biochemical pesticide against virus diseases on tobacco, with inhibitory of $31.8 \%$, was used as the positive control. Compounds $1(20 \mu \mathrm{M})$ showed moderate anti tobacco mosaic virus activity with inhibition rates of $\mathbf{1 8 . 2} \%$. Compounds $\mathbf{2 - 5}$ showed low anti tobacco mosaic virus activities with inhibitory rates below $10 \%$.

\section{ACKNOWLEDGEMENTS}

This project was supported financially by the Excellent Scientific and Technological Team of Yunnan High School (2010CI08), the Yunnan University of Nationalities Green Chemistry and Functional Materials Research for Provincial Innovation Team (2011HC008) and Open Research Fund Program of Key Laboratory of Ethnic Medicine Resource Chemistry (Yunnan University of Nationalities) (2010XY08).

\section{REFERENCES}

1. D.Y. Hong, Y.S. Lian and L.D. Shen, Flora of China, Science Press, Beijing, Vol. 73, p. 32 (1983).

2. Yunnan Corporation of Materia Medica, List of Chinese Herb Medicine Resources in 3, Yunnan, Science Publishing, p. 544 (1993).

3. Q.F. Duang, H. Zhao and Y.Q. Wang, J. Chin. Yunnan Med., 12, 39 (2003). 
4. Z.J. Chen, Q.H. Wei and J.Y. Zhou, Yunnan J. Tradit. Chin. Med. Mater., 27, 49 (2006).

5. R.Q. Mei, Q. Lu, Y.F. Hu, H.Y. Liu, F.K. Bao, Y. Zhang and Y.X. Cheng, Helv. Chim. Acta, 91, 90 (2008).

6. Q.F. Hu, X.S. Li, H.T. Huang, H.X. Mu, P.F. Tu and G.P. Li, Bull. Korean Chem. Soc., 33, 287 (2012).

7. X.M. Gao, H.X. Mu, X.S. Li, G.Y. Yang, G.P. Li and Q.F. Hu, J. Chin. Chem. Soc. (Taipei), 59, 540 (2012).

8. Q.F. Hu, X.S. Li, H.T. Huang, H.X. Mu, P.F. Tu and G.P. Li, Helv. Chim. Acta, 95, 349 (2012).

9. R.Q. Mei, Q. Lu, Y.F. Hu and Y.X. Cheng, Chin. J. Nat. Prod. Res. Develop., 22, 238 (2010).

10. D.Q. Yu and J.S. Yang, Handbook of Analytical Chemistry, Nuclear Magnetic Resonance spectroscopy, Chemical Industry Press, Beijing, edn. 2, Vol. 2, p. 323 (1999).

11. E. Dagne, A. Bekele and P.G. Waterman, Phytochemistry, 28, 1897 (1989)
12. D.S. Bhakuni and R. Chaturvedi, J. Nat. Prod., 47, 585 (1984).

13. Y. Yang, T. Zhang, L. Xiao, L.X. Yang and R.Y. Chen, Fitoterapia, 81, 614 (2010).

14. X.M. Gao, L.Y. Liying Yang, Y.Q. Shen, L.D. Shu, X.M. Li and Q.F. Hu, Bull. Korean. Chem. Soc., 33, 2447 (2012).

15. X.M. Gao, L.Y. Yang, L.D. Shu, Y.Q. Shen, Y.J. Zhang and Q.F. Hu, Heterocycles, 85, 1925 (2012).

16. X.M. Gao, L.Y. Liying Yang, Y.Q. Shen, L.D. Shu, X.M. Li and Q.F. $\mathrm{Hu}$, Bull. Korean. Chem. Soc., 33, 2447 (2012).

17. Z.L. Geng, S.H. Shang, X.J. Chen and Y. Cao, Chin. Tob. Sci., 32, 84 (2011).

18. X.M. Gao, X.S. Li, X.Z. Yang, H.X. Mu, Y.K. Chen, G.Y. Yang and Q.F. Hu, Heterocycles, 85, 147 (2012).

19. Q.F. Hu, B. Zhou, X.M. Gao, L.Y. Yang, L.D. Shu, Y.Q. Shen, G.P. L, C.T. Che and G.Y. Yang, J. Nat. Prod., 75, 1909 (2012).

20. B.A. Song, H.P. Zhang, H. Wang, S. Yang, L.H. Jin, D.Y. Hu, L.L. Pang and W. Xue, J. Agric. Food Chem., 53, 7886 (2005). 